\title{
PROFILE OF SCIENTIFIC LITERACY BASED ON DAILY LIFE PHENOMENON: A SAMPLE TEACHING FOR STATIC FLUID
}

\author{
Luluk Waki'a ${ }^{1}$, Titin Sunarti ${ }^{2}$ \\ ${ }^{1,2}$ Program Studi Pendidikan Fisika, Jurusan Fisika, MIPA, Universitas Negeri Surabaya \\ Surabaya, Indonesia \\ lulukwaki.a@gmail.com
}

Accepted: April 30, 2021

Published: May 5, 2021

DOI: $10.21107 /$ jps.v8i1.10272

\begin{abstract}
The purpose of this study is to describe the daily phenomenon-based physics literacy profile in static fluid material to find out how far the students' abilities about scientific science. Previously, the development of a daily phenomenonbased scientific literacy test instrument adjusted to the scientific literacy competency indicators and the applicable curriculum was carried out. This study used a quantitative descriptive method with a Research and Development model and is conducted on 40 students of SMAN 4 Sidoarjo at XI-MIPA class. The assessment instrument developed is stated theoretically and empirically valid. The theoretical validity is $83 \%$ which includes material, construct, and language criteria. The empirical validity includes the reliability test with a reliability coefficient of 0.782 (reliable). The item validity test states 15 valid questions with low to very high categories, the difficulty level with 13 moderate questions, and the distinguishing power with 13 questions in the sufficient to good category. Of the four categories of practical feasibility, 12 questions out of 15 (80\%) met the criteria and were eligible to be tested. The categories of each indicator of scientific literacy competence are indicators that explain phenomena scientifically in the moderate category (63.0\%), indicators of evaluating and designing scientific investigations in the very low category (43.7\%), and indicators of interpreting data and evidence in the very low category (52.7\%). It can be concluded that the average percentage of students' physics science literacy ability is 53\%, which is included in the very low category.
\end{abstract}

Keywords: daily phenomenon, scientific literacy profile, static fluid.

\footnotetext{
${ }^{1}$ Corresponding Author
} 


\section{Introduction}

Assessment is the process of collecting information about students and the class to make instructional decisions (Arends, 2012). Legislation No.19 of 2005 on National Education Standards Chapter 1 Article 1, paragraph 17 states that the assessment collects and processes information to measure student achievement. Thus the assessment is a matter that must be implemented in the learning process for evaluating the results obtained during the process.

Assessment is carried out at the national and international level in the international student assessment program or Program for International Student Assessment (PISA). PISA assessment program is expected to assess the quality of education at a young age school children for the challenges of human resources in the 21 st century (Pratiwi, 2019). Three aspects were assessed, namely, scientific literacy, mathematics, and reading. Meanwhile, Indonesia still ranks poorly. Indonesia is in the bottom ten rankings in 2018, ranking 74 out of 79 countries with an average scientific literacy score of 389 from the OECD average score of 489 (Kemendikbud, 2019). Indonesia still has very little awareness of education, one of the causes for the low level of scientific literacy.

Several factors cause the low level of scientific literacy in Indonesia, including textbook selection, misconceptions, un-contextual learning, low reading skills, and a learning environment that is not conducive (Fuadi, Robbia, Jamaluddin, \& Jufri, 2020). In addition, the learning process tends to use memorization as a vehicle for mastering knowledge, not thinking skills (Mardhiyyah, Ruslowati, \& Linuwih, 2016).

Scientific literacy is knowledge and scientific skills through the identification of questions, thus obtaining new knowledge, explaining scientific phenomena, making conclusions based on facts, understanding the characteristics of science, awareness of how science and technology shape the natural, intellectual and cultural environment, and the willingness to be involved and care about science-related issues (OECD, 2017). Based on the 2013 revised curriculum, scientific literacy is indispensable in learning how far students understand science. According to the explanation of the Vice Minister of Education and Culture regarding the concept and implementation of the 2013 Curriculum, it is stated that future challenges must be faced with future competencies as well (Vice Minister of Education and Culture, 2014). In addition, scientific literacy can be used as a personal and social problem-solving skill (Lederman, Lederman, \& Antink, 2013).

The scientific literacy assessment conducted by PISA is only intended for students aged 15 years and under, while for students aged 15 years and over, the equivalent of high school students is not considered. It shows that a scientific literacy assessment instrument is needed for high school students to measure how high school students can scientific literacy and advance the quality of education in Indonesia (Indrawati \& Sunarti, 2018).

Research related to scientific literacy has been done a lot, both the development of test instruments and students' scientific literacy profiles. However, the existing research is still limited in terms of material, item, and population coverage, so other developments related to scientific literacy need to be carried out. Indrawati (2018), in his research on the development of scientific literacy instruments on the discussion of waves, has been able to develop theoretically and empirically valid test instruments. However, the coverage of the material and population is still limited. Several researchers, Parno (2018), analyzed the profile of scientific literacy on the discussion of dynamic fluids. 2) Tulaiya (2020) analyzed scientific literacy skills in heat material. And 3) Lestari (2020) the feasibility of formativebased instruments on the discussion of global warming.

Physics is one of the branches of science, a science closely related to human life (Harefa, 2019). Students are required to know concepts and are required to apply learning concepts to their daily lives. Learning with scientific literacy not only aims to gain knowledge with high cognitive value but also requires the application of knowledge to life and interactions with nature (Putri, Ramalis, \& Purwanto, 2018). Learning with scientific literacy skills encourages the ability to analyze scientific information to obtain new knowledge (Bybee \& McCrae, 2011). Learning science literacy skills is related to applying, synthesizing, and evaluating existing information effectively (Whittingham, Huffman, Rickman, \& Wiedmaier, 2013).

Learning physics by applying concepts to the phenomena of everyday life is following scientific literacy and competency standards. One of the materials in physics that has many applications in everyday life is static fluid material. Students can easily find applications of the concept of static fluids because their use is side by side with 


\section{Profile of Scientific Literacy-Based On Daily Life Phenomenon}

everyday life. The application of static fluids in everyday life ships, for instance, the buoyancy that acts on the ship, can make the ship float well. This buoyancy makes use of static fluid material, namely in the discussion of Archimedes' law. Some other examples are submarines, hot air balloons, hydraulic pumps, and others. It shows that physics is very useful for life if realized in technology (Harefa, 2019).

Milanto (2021) stated that a test instrument had been developed in the discussion of static fluids about the scientific literacy profile of students. However, the discussion used does not cover the entirety of the inert fluid material. In addition, no discussion shows the application of physics in everyday life. Physical science literacy assessment instruments based on everyday life phenomena, especially for high school students, are needed to familiarize the students.

\section{Research Methods}

This research uses a quantitative descriptive method with a Research and Development Development model, including a preliminary study stage, model development, and testing (Saputro, 2016). At the preliminary study stage, potential and problem analysis was carried out and a literature review. Second, the model development stage was carried out by making a test instrument in 15 essay questions on static fluid material. Finally, the testing phase of the instrument developed, has been validated by two experts, was tested on 40 students of SMAN 4 Sidoarjo in class XI MIPA 1 - XI MIPA 4.

The data were collected using the scientific literacy test instrument sheet and the validation sheet. The validity test of the instrument was carried out by two methods, namely theoretical validity, and empirical validity. The theoretical validity is based on the validation results by two experts with aspects of material, construction, and language. Meanwhile, empirical validity is based on the criteria for measuring the items, reliability, difficulty level and distinguishing power. Then an analysis of the students' scientific literacy profiles was carried out. Students' scientific literacy indicators are adjusted to scientific literacy competencies, namely, explaining phenomena scientifically, evaluating and designing scientific investigations, and interpreting data and evidence scientifically (OECD, 2019). The criteria for assessing students' scientific literacy are grouped into very high, high, medium, low, and very low criteria (Purwanto, 2008) in Table 1.
Table 1. Scientific literacy profile assessment criteria

\begin{tabular}{lc}
\hline \multicolumn{1}{r}{ Category } & Interval \\
\hline Very high & $86-100$ \\
High & $76-85$ \\
Medium & $60-75$ \\
Low & $55-59$ \\
Very low & $\leq 54$ \\
\hline
\end{tabular}

\section{Result and Discussion}

The development of a scientific literacy test instrument is based on the standard PISA scientific literacy competencies and is adjusted to the basic competencies in the 2013 Curriculum. Given the low literacy ratings of students, it is necessary to involve literacy questions in learning, especially those related to the phenomena of everyday life. The static fluid used in the research is adapted to everyday life, including Archimedes' law, capillary action, Pascal's law, hydrostatic pressure, surface tension, and viscosity. The instruments developed were validated theoretically and empirically.

\section{Theoretical Validity}

Two lecturers theoretically validated the instrument that was successfully developed. The aspects that are validated include aspects of material, construction, and language. Figure 1 is a diagram of the percentage of theoretical validity of each aspect.

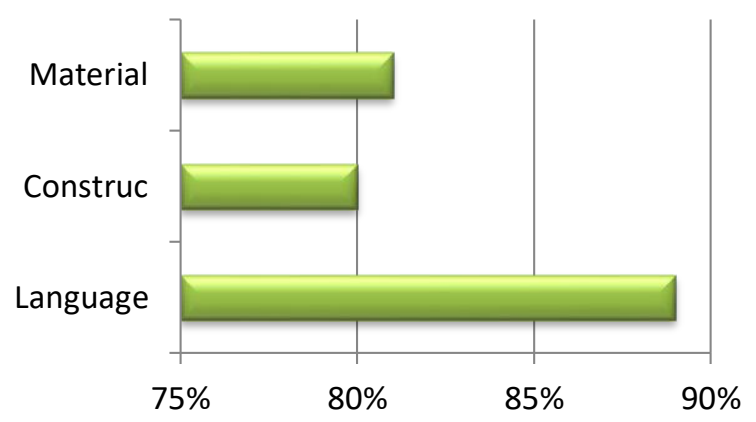

Figure 1. Percentage of theoretical validity

The results of theoretical validation by two experts get a percentage of $83 \%$ with valid criteria. The test instrument is declared valid based on the validity criteria if the validation percentage obtained more than $60 \%$ (Arikunto, 2014). Thus, the 15 questions developed were declared valid and could be used for trials with revision adjustments. The results of the percentage of theoretical validity for each criterion are shown in Figure 1. 


\section{Wakiá \& Sunarti}

\section{Empirical Validity: Item Validity}

The validity test of the items was obtained from calculations using the Pearson productmoment correlation based on the results of the scores for each item with the total scores obtained by students in the trial. The results of the item validity test can be seen in Figure 2 .

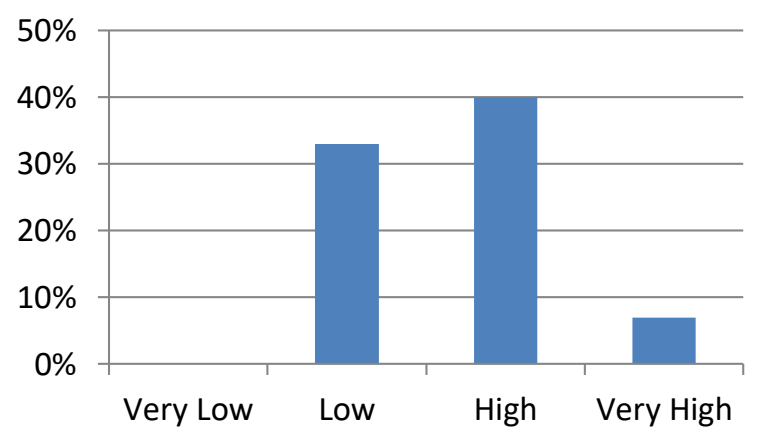

Figure 2. Validity of the items

The empirical validity is based on the reliability test results, the validation of the items, the difficulty level, and the distinguishing power. Reliable means trustworthy, so instruments that are declared reliable are instruments whose measurement results can be trusted (Asrul, Ananda, \& Rosnita, 2014). Based on the results of reliability calculations with Alpha Cronbach's formula in (Widiyanto 2018), the instrument developed was declared reliable with a reliability coefficient (r11) of 0.782 . When compared with the product-moment coefficient value (table $\mathrm{r}$ ) at $\mathrm{N}$ $=39$ with a significance of $5 \%$, namely 0.316 , then $\mathrm{r} 11>\mathrm{r}$ table or $0.782>0.316$. A reliable instrument is an instrument that can be used repeatedly, and the measurement results are fixed (Asrul, Ananda, \& Rosnita, 2014).

The validity of the items in Figure 2 shows the percentage of validity of each item in the very low to very high category. Of the 15 questions tested, there were $0 \%$ of the questions in the very low category. It can be interpreted that there are no invalid questions. For questions in the low category as many as $33 \%$ or five questions, namely numbers $6,9,11,13$, and 14 , the moderate category is $40 \%$ or six questions, namely numbers $1,2,3,8,10$, and 12 , the high category is $20 \%$ or three questions, namely numbers 4,5 , and 15 , and the very high category is $7 \%$ or 1 question in number 7. From these categories, it is stated that as many as 15 questions are valid. The validity of the questions is determined by calculating the correlation coefficient using the Pearson productmoment correlation formula and comparing it with the $r$ table. From the calculation results for the low to very high category, the value $r>r$ table $=0.32$, so it can be concluded that the fifteen questions developed were declared valid through the item validity test.

\section{Level of Difficulty}

The difficulty level is obtained from calculating the average score of each item compared to the maximum score of the questions used. From the calculation results, the percentage of difficulty level for each item from easy to difficult categories can be seen in the diagram in Figure 3.

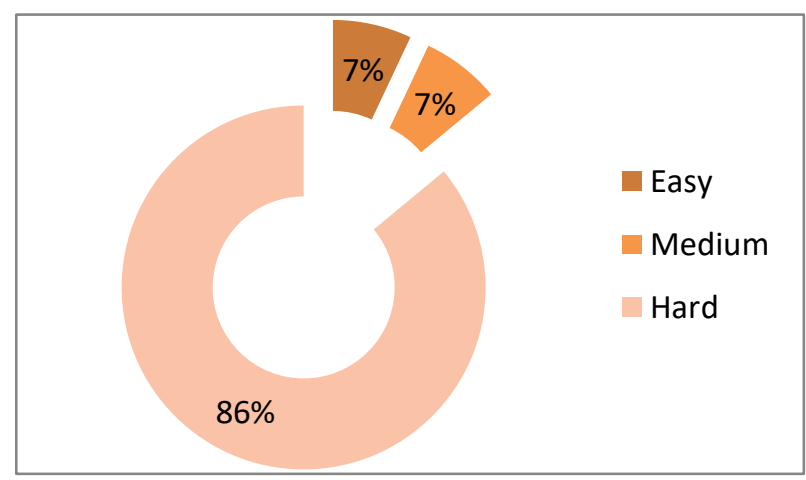

Figure 3. Level of Difficulty

The difficulty level (Figure 3) shows that $87 \%$ of the questions have categorized a medium, and $7 \%$ were categorized as easy and difficult. It shows that as many as $87 \%$ or 13 questions are reasonable or feasible questions to use. A good problem is neither too easy nor too difficult to solve. (Widiyanto, 2018). On the other hand, $7 \%$ or one question from the easy and difficult categories is not suitable for use. Easy questions are found in number 1, and difficult questions are in number 11 . The rest are in the medium category.

\section{Discriminating power}

The discriminating power of each item is determined from the coefficient of difference in the difference in the average grouping of upper and lower class students compared to the maximum score. The discriminating power test is presented in the diagram in Figure 4.

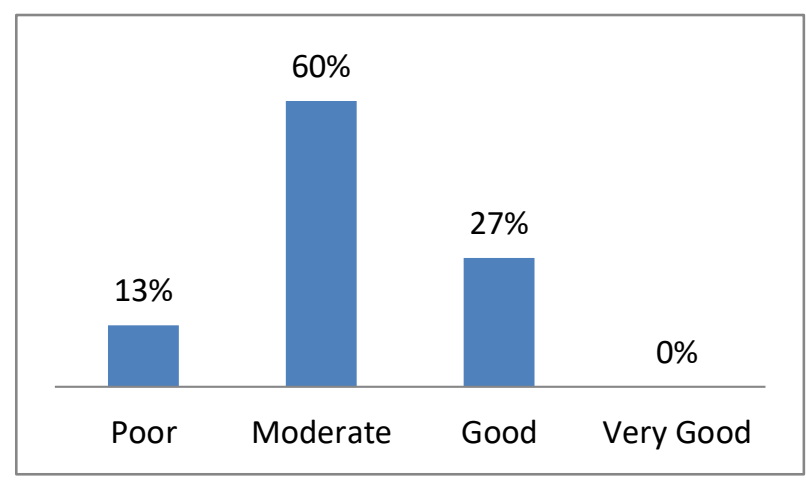

Figure 4. Discriminating Power 


\section{Profile of Scientific Literacy-Based On Daily Life Phenomenon}

The discriminating power in Figure 4 shows that of the 15 questions developed. There were $13 \%$ or two questions in the poor category, $60 \%$ or nine questions in the moderate category, $27 \%$ or four questions in the good category, and $0 \%$ or no questions in the category very good. This percentage shows that as many as 13 questions from the sufficient and good categories are feasible to use. Meanwhile, two questions from the unfavorable category, namely numbers 11 and 13, were not suitable for use or needed consideration. The coefficient of difference can differentiate between smart students (upper class) and stupid students (lower class). The greater the coefficient of difference, the better the problem is. A low coefficient of difference cannot distinguish between upper and lower classes, meaning that smart and stupid students can do them or smart or stupid students cannot do them. Good questions are questions that only smart students can answer. (Widiyanto, 2018).

Questions that can be used for data collection meet the four criteria of empirical validity testing. These four criteria must be met because they are related to one another. Of the 15 questions developed, 12 questions were feasible and met the four criteria, and three questions were not feasible, namely numbers 1,11 , and 13 .

\section{Student Science Literacy Profile}

After testing the instrument's validity, and analysis of the students' physics science literacy profile was analyzed. The categories of students' physics science literacy profile based on the percentage of values can be seen in table 2 .

Knowledge of science in scientific literacy is limited to knowledge and how the process of knowing is applied to the surrounding life (Mardhiyyah, Ruslowati, \& Linuwih, 2016). According to the PISA definition, scientifically literate someone is capable and willing to engage in reasoned discourse about science and technology (OECD, 2016).

Table 2. Science Literacy Profile on Physic

\begin{tabular}{lcc}
\hline \multicolumn{1}{c}{ Category } & Number of Students & Percentage \\
\hline Very High & 0 & $0 \%$ \\
High & 2 & $5 \%$ \\
Moderate & 9 & $23 \%$ \\
Low & 8 & $20 \%$ \\
Very low & 21 & $53 \%$ \\
\hline Total & 40 & \\
\hline
\end{tabular}

The average value obtained is 39.85 , with a percentage of $53 \%$. This percentage value is obtained from calculating the mean score of the experimental students compared to the maximum score of 75 . Thus, from this value, it can be categorized that students' average science literacy ability is in the very low category. If viewed from each item, the students' physics science literacy skills can be categorized in Table 3 .

Based on Tables 2 and 3, the percentage of students' physics science literacy abilities varies. If viewed from the indicators of each item, it can be grouped into indicators of scientific literacy as in Table 4. Based on Tables 2 and 3, the percentage of students' physics science literacy ability varies. If viewed from the indicators of each item, they can be grouped into indicators of scientific literacy as in Table 4.

The results of the test on students can be analyzed the profile of the physics science literacy. Based on Table 2, the students' physics science literacy profiles at SMAN 4 Sidoarjo vary from very low to high. The average scientific literacy ability of students is in the very low category. It shows that the students' physics science literacy skills are still below standard if viewed from the indicators of each item and indicators of scientific literacy as in Tables 3 and 4.

\section{Indicators: explain phenomena scientifically}

Students are expected to recognize, offer, and evaluate explanations for various natural and technological phenomena (OECD, 2016). Based on Table 4, students' scientific literacy abilities on this indicator fall into the medium category. That is, some students can recognize, offer, and evaluate explanations of natural phenomena and technology. For question number 1, students' scientific literacy falls into the medium category with the questions in Figure 5. 
Table 3. Percentage of students' scientific literacy per item

\begin{tabular}{|c|c|c|c|}
\hline Indicator & $\begin{array}{l}\text { Item } \\
\text { number }\end{array}$ & Percentage & Category \\
\hline $\begin{array}{l}\text { Explain how the fluid works on the upward force of objects } \\
\text { based on scientific phenomena according to Archimedes' Law. }\end{array}$ & 1 & $72 \%$ & Medium \\
\hline $\begin{array}{l}\text { Explain the position of fluid to an event based on scientific } \\
\text { phenomena according to capillary symptoms. }\end{array}$ & 2 & $55 \%$ & Low \\
\hline $\begin{array}{l}\text { Formulate a hypothesis of the impact of fluids on an event based } \\
\text { on scientific phenomena according to capillary symptoms. }\end{array}$ & 3 & $68 \%$ & Medium \\
\hline $\begin{array}{l}\text { Explain the benefits of the application of fluids in life-based on } \\
\text { scientific phenomena according to Pascal's Law. }\end{array}$ & 4 & $65 \%$ & Medium \\
\hline $\begin{array}{l}\text { Explain the role of fluids on the buoyancy of objects based on } \\
\text { scientific phenomena according to Archimedes' Law. }\end{array}$ & 5 & $56 \%$ & Low \\
\hline $\begin{array}{l}\text { Identify the efficiency of using an object in a fluid based on } \\
\text { scientific phenomena according to Archimedes' Law. }\end{array}$ & 6 & $59 \%$ & Low \\
\hline $\begin{array}{l}\text { Write the correct problem formulation based on scientific } \\
\text { phenomena according to Hydrostatic Pressure. }\end{array}$ & 7 & $41 \%$ & Very Low \\
\hline $\begin{array}{l}\text { Interpret scientific variables based on scientific phenomena } \\
\text { according to Hydrostatic Pressure. }\end{array}$ & 8 & $40 \%$ & Very Low \\
\hline $\begin{array}{l}\text { Evaluating the method used for the investigation of submarine } \\
\text { motion based on scientific phenomena according to Archimedes' } \\
\text { Law. }\end{array}$ & 9 & $37 \%$ & Very Low \\
\hline $\begin{array}{l}\text { Describe and evaluate the methods Archimedes uses to ensure } \\
\text { the accuracy of data based on scientific phenomena. }\end{array}$ & 10 & $43 \%$ & Very Low \\
\hline $\begin{array}{l}\text { The graphical data represents the relationship between the mass } \\
\text { of substance and density in description based on scientific data } \\
\text { according to the density of the substance. }\end{array}$ & 11 & $30 \%$ & Very Low \\
\hline $\begin{array}{l}\text { Analyze the conclusions of the data in an experiment based on } \\
\text { scientific research according to Archimedes Law. }\end{array}$ & 12 & $60 \%$ & Medium \\
\hline $\begin{array}{l}\text { Identify assumptions, evidence, and reasons related to an event } \\
\text { based on scientific phenomena according to the principles of } \\
\text { Archimedes Law. }\end{array}$ & 13 & $36 \%$ & Very Low \\
\hline $\begin{array}{l}\text { Distinguish between assumptions based on scientific evidence or } \\
\text { assumptions based on other considerations based on scientific } \\
\text { phenomena according to the principle of surface tension. }\end{array}$ & 14 & $71 \%$ & Medium \\
\hline $\begin{array}{l}\text { Evaluate the scientific assumptions and evidence of the dewdrop } \\
\text { phenomenon according to the surface tension principle. }\end{array}$ & 15 & $68 \%$ & Medium \\
\hline
\end{tabular}

Table 4. Percentage of students' scientific literacy abilities based on scientific literacy indicators

\begin{tabular}{lccc}
\hline \multicolumn{1}{c}{ Science Literacy Indicators } & $\begin{array}{c}\text { Item } \\
\text { Number }\end{array}$ & Percentage & Category \\
\hline Explain phenomena scientifically & $1-5$ & $63,0 \%$ & Low \\
Evaluating and designing scientific investigations & $6-10$ & $43,7 \%$ & Very Low \\
Interpret data and evidence scientifically & $11-12$ & $52,7 \%$ & Very Low \\
\hline
\end{tabular}




Pada festival balon
udara yang diisi 5
orang dewasa
diterbangkan pada
ketinggian $5 \mathrm{~m}$.
Balon udara
tersebut diisi dengan gas helium sebagai
bahan bakar. Setelah beberapa saat berada di
ketinggian $5 \mathrm{~m}$, balon udara dinaikkan
setinggi $3 \mathrm{~m}$. Kemudian saat hendak turun
kembali ke permukaan balon udara
diturunkan secara perlahan sampai ke dasar.
Bagaimana balon udara dapat naik dan turun
di udara ? Apakah yang perlu diubah jika
kapasitas balon udara ditambah menjadi 5
orang dewasa? Jelaskan!

Figure 5. Problem number 1

In this question, almost all students have understood the meaning of the problem. Some of the answers are not quite right because students do not understand the application of physics to hot air balloons. Thus, it cannot explain how the lift force works in a hot air balloon. For question number 2, students' scientific literacy was in a low category; by applying the ink liquid pattern event to the uniform, most students understood the question's meaning, but some students did not understand the questions. However, most students do not understand that fluid position in the questions is included in capillary action.

For question number 3, the students' scientific literacy was in the medium category who used the flood phenomenon application. Most of the students gave the correct hypothesis, but few gave the right reasons. The correct hypothesis is obtained by students from reasoning based on the phenomena that occur. The answer is inaccurate because students do not understand the relationship between capillary subjects and the application to the questions. For question number 4 , the students' scientific literacy was in the medium category who used hydraulic machine technology in the car wash. Most of the students were able to understand the meaning of the questions and answer them correctly. Students who answer incorrectly most do not understand that the application of hydraulic machines in car washing is included in the benefits of fluids, namely Pascal's Law.

For question number 5, students' scientific literacy was low using ships at tourist attractions with different passenger capacities. Most of the students answered wrong. Students' incorrect answers were dominated by inaccurate predictions or problem analysis. They answered that the ship's mass, ship size, and sea waves influenced the ship to float. However, some students answered correctly for the right reasons, namely because the ship has a buoyancy force adjusted to the ship's capacity, volume, and hull.

Indicators: evaluate and design scientific investigations

Students are expected to describe and assess scientific investigations and propose ways of solving a problem scientifically (OECD, 2016). From Table 4, it is known that on this indicator, students' scientific literacy skills are in the very low category. Students' ability to evaluate and design scientific investigations is below average. For question number 6, the students' scientific literacy was in the low category carrying ship applications with different hull shapes. Students who have high thinking skills can analyze the hull's efficiency by looking at the pictures provided in the questions.

Meanwhile, students with low analytical skills will relate the shape and size of the ship to the hull's efficiency. So, students with this type do not understand the meaning of the question command asked. Many students can only answer the type of stomach that is effective without giving reasons, or the reasons given are not quite right. It is because students only guess which stomach is roughly effective without thinking about what makes it effective. For number 7 it is in the very low category with the questions in Figure 6.

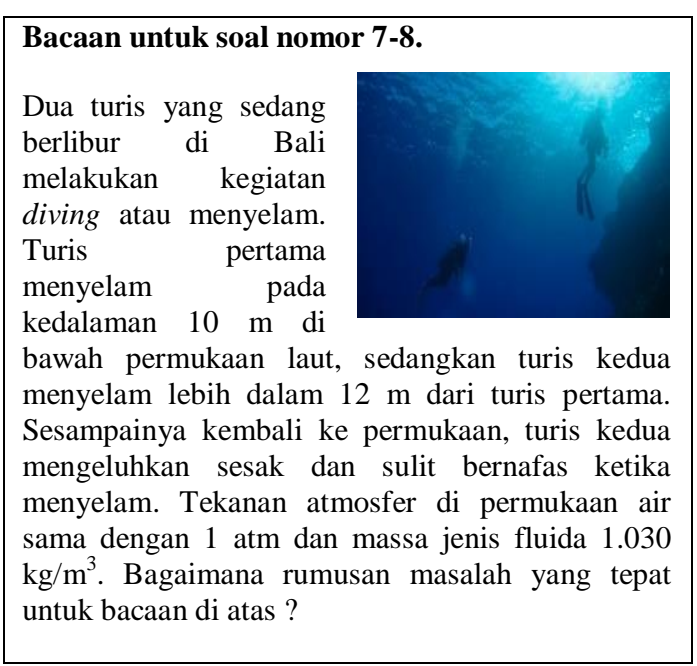

Figure 6. Example problem number 7.

The average student's answers did deviate from the questions, and many answered the conclusions of the phenomena in reading. It proves that students do not know the meaning of the questions about the problem formulation. For question number 8 , students' scientific literacy was 


\section{Wakiá \& Sunarti}

in the very low category, reading the same question as number 7 . It was still related to the design of scientific investigations, namely interpreting scientific variables. Like problem formulation, most students do not know scientific variables (bound, manipulation, response). For question number 9 , students' scientific literacy fell into the very low category using the submarine application. Most students cannot evaluate the motion of the submarine, which is included in the Archimedes Law material. Some students only answer the points without explaining the evaluation, or the evaluation given is not correct. For question number 10, students' scientific literacy fell into the very low category using the experimental phenomenon of scientists, namely the Archimedes experiment in determining density. On average, students are not able to evaluate a method that Archimedes has done in the experiment. It proves that the ability to evaluate students is still very low.

\section{Indicators: interpret data and evidence in a scientific manner}

In this indicator, students are expected to analyze and evaluate data scientifically, explain in various representations, and draw the correct conclusions (OECD, 2016). The students 'scientific literacy profile on this indicator is in the very low category (Table 4), which means that the students' ability to interpret scientific data and evidence is below the average. For question number 11, the students' scientific literacy was in the very low category (Figure 7).

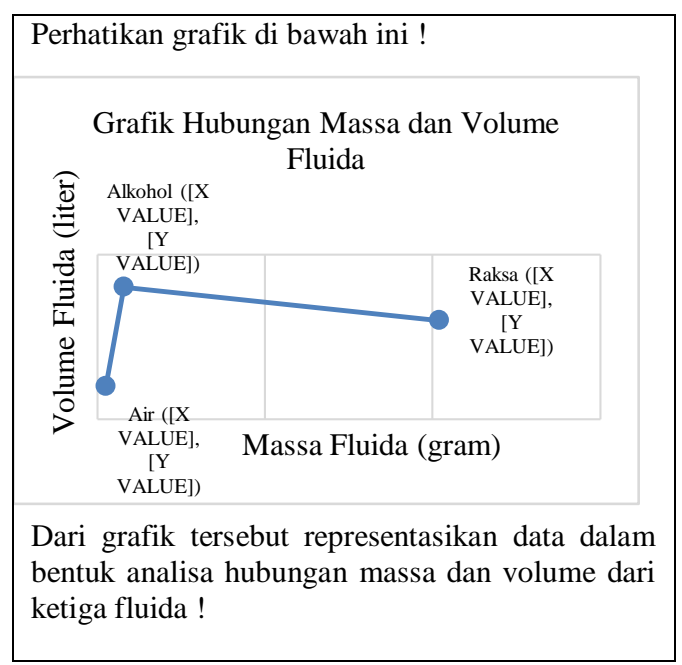

Figure 7. Example problem number 11

This question is presented in graphical form. None of the forty students had the correct answer. It shows that all students cannot analyze data in graphical form and interpret it in descriptions. For question number 12, the students' scientific literacy was in the medium category using experimental data on the viscosity of three different fluids. The average answer given by students can guess the most significant fluid viscosity coefficient, but no scientific evidence and explanation are given to support this answer. It shows that students do not fully understand the concept of viscosity and its application in everyday life. Students can only shoot from the viscosity of the fluid. For question number 13, students 'scientific literacy was in the very low category by using experimental pictures of eggs and salt solution according to Archimedes' Law. The average student's answer is wrong. It shows that students have not been able to identify assumptions, evidence, and reasons for the experimental results presented.

For question number 14, students' scientific literacy fell into the medium category. In this problem, two figures are presented, which represent the phenomenon of surface tension and not. Students were asked to distinguish which of the two images included a scientific assumption of surface tension. Of all the students' answers, most of them answered correctly. However, only a few answered with scientific reasons. It shows that students who answered correctly without scientific reasons only guessed from pictures and explanations without knowing surface tension in the questions. For question number 15, the students' scientific literacy was in the medium category. Most of the students' answers were correct. However, some answers do not include an evaluation of the assumptions or evidence sections. It shows that students do not master how to interpret data and scientific evidence.

The trials were carried out using valid instruments with medium question categories. The instrument used contained questions about the phenomena of everyday life so that students could more easily understand the application of physics in life. However, the students 'scientific literacy results were at very low criteria, meaning that the student's abilities were still below average. Based on previous studies, the ability of students to evaluate and design scientific investigations is, on average lower than the other two categories (Milanto, Zainuddin, \& Setyarsih, 2021). Similar to the results of previous studies, in this study, the highest average ability of students was to explain phenomena scientifically.

Students' literacy skills at SMAN 4 Sidoarjo are not yet good because learning is done online or online because it is still during the Covid-19 pandemic. It hinders learning which should be explained directly through student experiments and experiments. Online learning is considered less 


\section{Profile of Scientific Literacy-Based On Daily Life Phenomenon}

effective, especially in physics, because of the reduced time for active learning and limited technology to explain learning in detail. Providing scientific literacy to students is only done implicitly through informing several technologies being applied in direct learning, both scientifically analyzing and evaluate. In this case, increasing students' scientific literacy relies not only on the role of a teacher. According to (Treacy \& Melissa, 2011), increasing scientific literacy can be obtained from reading, writing, and reviewing journals. In addition, students must also have the ability to study literature critically and scientifically (Jurecki \& Wander, 2012).

\section{Conclusion}

The developed instrument for assessing physical science literacy based on everyday life phenomena for students is theoretically and empirically feasible. The theoretical validity is $83 \%$ which includes material, construct, and language criteria. The empirical validity of $80 \%$ or 12 of the 15 questions were declared valid, which included the criteria for item validity, reliability, difficulty level, and distinguishing power. The average physical science literacy ability based on the phenomena of everyday life on static fluid material for students of SMAN 4 Sidoarjo is in the very low category with a percentage of $53 \%$. Some of the criteria for indicators of scientific literacy, namely, indicators explain phenomena scientifically in the moderate category $(63.0 \%)$, indicators evaluate, and scientific design investigations in the very low category $(43.7 \%)$, and indicators interpret data and evidence scientifically in the very low category (52.7\%).

The physical science literacy assessment instrument based on the phenomena of everyday life that has been developed is feasible to be tested and used as an evaluation tool in learning. Further research related to assessment instruments is needed, especially in a more detailed discussion regarding aspects of scientific literacy and how to improve students' scientific literacy skills through learning, both online and offline.

\section{References}

Arends, R. I. (2012). Learning to Teach. New York: McGraw-Hill.

Arikunto, S. (2014). Prosedur Penelitian : Suatu Pendekatan Praktik. Jakarta: PT. Rineka Cipta.

Asrul, Ananda, R., \& Rosnita. (2014). Evaluasi Pembelajaran. Medan: Citapustaka Media.

Asyhari, A. (2019). Pengembangan Instrumen Asesmen Literasi Sains Berbasis Nilai-Nilai Islam Dan
Budaya Indonesia Dengan Pendekatan Kontekstual. Lentera Pendidikan, 2, 14.

Bybee, R., \& McCrae, B. (2011). Scientific literacy and student attitudes: Perspectives from PISA 2006 science. International Journal of Science Education, $\quad$ Vol. $\quad 33(1)$ : $\quad$ 7-26. doi:10.1080/09500693.2011.518644

Fuadi, H., Robbia, A. Z., Jamaluddin, \& Jufri, A. W. (2020). Analisis Faktor Penyebab Rendahnya Kemampuan Literasi Sains Peserta Didik. Jurnal Ilmiah Profesi Pendidikan, Volume 5, Nomor 2, 9.

Harefa, A. R. (2019). Peran Ilmu Fisika Dalam Kehidupan Sehari-Hari. Jurnal Warta Edisi : 60, 10.

Indrawati, M. D., \& Sunarti, T. (2018). Pengembangan Instrumen Penilaian Literasi Sains Fisika Peserta Didik Pada Bahasan Gelombang Bunyi Di Sma Negeri 1 Gedangan Sidoarjo. Jurnal Inovasi Pendidikan Fisika (JIPF), Universitas Negeri Surabaya, 7.

Jurecki, K., \& Wander, M. C. (2012). Science Literacy, Critical Thinking, and Scientific Literature: Guidelines for Evaluating Scientific Literature in The Classroom. Journal of Geoscience Education, 60(2), 100-105.

Kemendikbud. (2019, Desember 4). Hasil PISA Indonesia 2018: Akses Makin Meluas, Saatnya Tingkatkan Kualitas. Diambil kembali dari kemendikbud:

https://www.kemdikbud.go.id/main/blog/2019/1

2/hasil-pisa-indonesia-2018-akses-makin-

meluas-saatnya-tingkatkan-kualitas

Lederman, N. G., Lederman, J. S., \& Antink, A. (2013). Nature of Science and Scientific Inquiry as Contexts for The Learning of Science and Achievement of Scientific Literacy. International Journal of Education in Mathematics, Science, and Technology, 1(3).

Lestari, D., \& Setyarsih, W. (2020). Kelayakan Instrumen Penilaian Formatif Berbasis Literasi Sains Peserta Didik Pada Materi Pemanasan Global. IPF : Inovasi Pendidikan Fisika, 09 (03), $561-570$

Mardhiyyah, L. A., Ruslowati, A., \& Linuwih, S. (2016). Pengembangan Instrumen Asesmen Literasi Sains Tema Energi. Journal of Primary Education, 8. Diambil kembali dari http://journal.unnes.ac.id/sju/index.php/jpe

Milanto, S., Zainuddin, A., \& Setyarsih, W. (2021). Profil Kemampuan Literasi Sains Peserta Didik SMA di Kabupaten Pamekasan Dalam Bahasan 


\section{Wakiá \& Sunarti}

Fluida Statis. IPF : Inovasi Pendidikan Fisika, $10(1), 59-65$.

Parno, L, Y., \& N, M. (2018). The Profile of High School Students' Scientific Literacy on Fluid Dynamics. Journal of Physics: Conference Series. doi:10.1088/1742-6596/1013/1/012027

Pratiwi, I. (2019). Efek Program PISA Terhadap Kurikulum di Indonesia. Jurnal Pendidikan dan Kebudayaan, $\quad$ Vol. $\quad 4, \quad 21$. doi:10.24832/jpnk.V4i1.1157

Purwanto, M. (2008). Prinsip-Prinsip dan Teknik Evaluasi Pengajaran. Bandung: PT. Remaja Rosdakarya.

Putri, D. A., Ramalis, T. R., \& Purwanto. (2018). Pengembangan tes kemampuan literasi sains pada materi momentum dan impuls dengan Analisis Item Response Theory (IRT). JRKPF $U A D, 6$.

Sadler, T. D., \& Zeidler, D. L. (2009). Scientific Literacy, PISA, and Socioscientific Discourse: Assessment for Progressive Aims of Science Education. Journal of Research In Science Teaching, 13.

Saputro, B. (2016). Manajemen Penelitian Pengembangan. Salatiga: Aswaja Pressindo.

Treacy, D. J., \& Melissa, K. C. (2011). Using the Writing and Revising of Journal Articles to Increase Science Literacy and Understanding in a Large Introductory Biology Laboratory Course. Atlas Journal of Science Education, 1(2), 29-37.

Tulaiya, \& Wasis. (2020). Analisis Kemampuan Literasi Sains Peserta Didik SMA/MA di Kabupaten Sumenep. IPF : Inovasi Pendidikan Fisika, 09 (03), 417-427.

Wamendikbud. (2014). Konsep dan Implemetasi Kurikulum 2013.

Whittingham, J., Huffman, S., Rickman, W., \& Wiedmaier, C. (2013). Technological Tools for The Literacy Classroom. Hershey: PA: IGI Global.

Widiyanto, J. (2018). Evaluasi Pembelajaran. Madiun: UNIPMA PRESS. 